\title{
New Security Issues in a Globalized World
}

\author{
Liord AxWOKL'HY

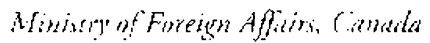

In the frot paper, the Cancdian Foretgrn Minister, the Honorable Llend Axuorthy outline: a proposal to expand the focus of the foretign poltry. activity of governments beyond the tratitional empitasis on a "hat" security agonda to tackle lisue's of immediate concem to individuals. $H_{c}$ bighlights, in particular, the ampaign to ban ant-personnel mines; offorts os combut interntional drug smugsling; and the continuing

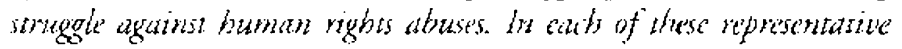
artas, the increst of indiziduals on the strezs of North American citices and in former combar zones in Ain and. Africa are of foremost concem.

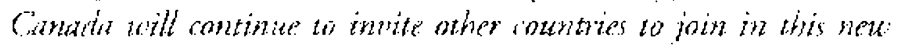
"tpprouth to the buman security challenge of our changing times.

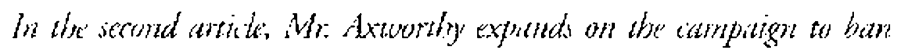

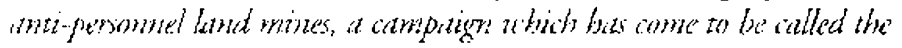

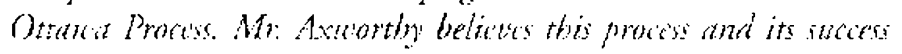

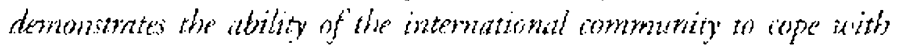
shanges and trends which bave emerged since the full of the Berlin Wall

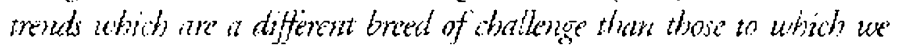
bat beiorie acustomed fin sa many years after the Sacond World War.

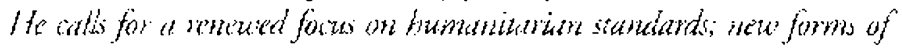

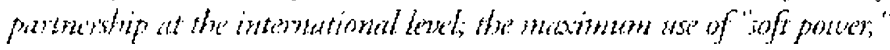

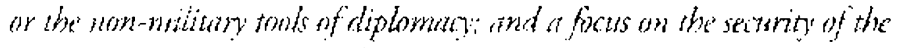

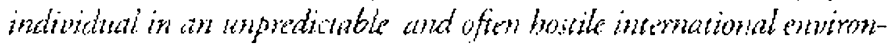
mem.

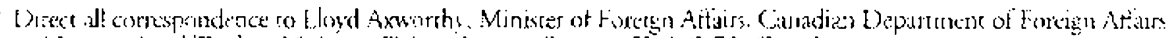

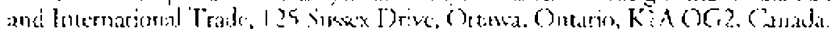




\section{Canada-Korea Security Cooperation: New Era, New Opportunities}

Timon an honoted to have this opporeunity to outline some recent directions in Canadian forcign policy, particularly in the area of henten securicy and to highlight the many: poists of comergence I see between the internatonal approaches waken by the Republic of horea and by Canada.

Starting with the fall of ate Berlin Wall, a series of unparalleled events have reshaped the international landscape into something we coudd scarcely have imagined a decade ago. Who would liave indigined then that it would take only a few years tor the Iron Curtain that had divided Europe for so long to shatcer completcly: That Nelson Mandelia would hecume Presiden of South Africa? That Kim Dasciung would become Presiden of rtre Repubilic of Korea:

The election of P'resident Kim, a man known for his legendary courage and his deep comminment to buman rights and democrax; is a symbol of the wave of democracy that has swepe the globe in the last decade. Through his far-siglued "sunstine policy" cowards Narsh Korca, Presiden Kim is a atiling one of the lase remnants of Cold War tensions.

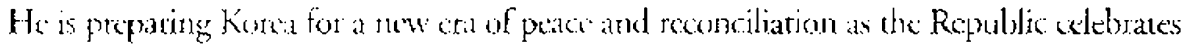
its lificth anniversing. (anada shates his hope that the intermationd wave of democtacy and aspece ho human rights will al last reach North Korea shores. Our policy of nortest diaiogue and humanitarian assistance to the DIPRK (Democratic l'eople's Republic of Koreal is directed cowards that end. I should act that in teeping with the policy, the

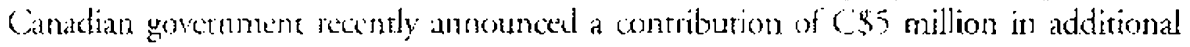
foud ald to limine vitims in North Koted.

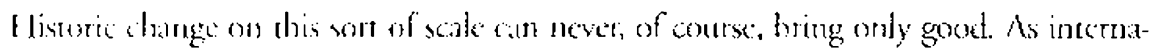
tional borders become mome porous. Foreign Ministers find themselves increasingly grappling, with issues dhit directly affece the daily lives of individuals: international crime. emvironmental degradation, humas rights abuses, and bitter internal conflicts. Most recently che Asian financial crisis has brought home the realities of the new global acomecimy:

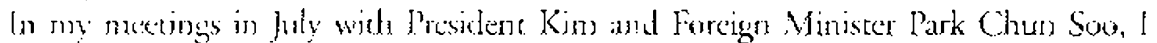
assured them of Canadi's continuad willingreses to assist Korea through these difficult

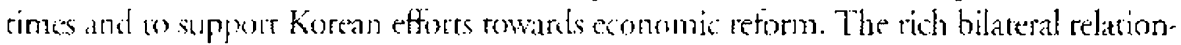
ship we enjow is buile an a srong onmitment to mutual prosperity for both our peoples. Candia was prompr in supporring kora thrugh its recent economic troubles with

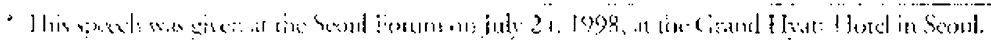


tangible financial assistance and continued open markets. We remain committed to a growing political and economic relationship.

It is particularly important that the international community address the severe human and sucial impact of the Asian financial crisis. At the last meeting of APEC foreign mintisters, we agreed on the nced to look at questions of social adjustment and human resoutces in the region. As a former Minister of Human Resources Development, these are issues I have a particular interest in. Now, with the financial crisis affecting the daily lives of millions of ordinary people, it is all the more urgent for us to work togethor to cnsure dhat problems in financial markets do not result in further social unrest and human hardship. Canada is supporring work within the World Bank and the Asian Devolopment Bank, as well as within our own bilatcral prograns, on this aspect of the crisis.

Be it financial crisis or the effects of environmental pollution, these problems are feit acutely at a local level, but tackling them effectively requires cooperation at the regional, and even the global, level. It also requires new international approaches and, in some cases, new institutions. After all, the traditional structures of international diplomacy were not formulared to deal with problems that largely ignore state boundarics.

In light of these changes, Canada's foreign policy has changed also. I have made "human sccurity" a major new focus: that is, the view that security goals should be primarily formulated, and achieved, in terms of human, not state, needs. When we took a lead in the campaign to ban anti-personnel mines, for example, our aim was to tackle the humanitarian crisis arising from the threat to millions of individuals posed by these weapons. Now we are working to improve human security in a range of other areas, in cooperation with likc-mindod governments.

This means tackling some of the human issues often overlooked by traditional approaches to international security: issues like the fate of childten in armed conflict or forced into exploitative forms of labor; like the battle against transnational organized crime: like the need for an International Criminal Court. Akong with other like-minded stares. such as Korea, we want to work together to change the foreign policy equation. The old approaches to international security simply will not solve problems of the son 1 fave listed. Instcad, we want to develop a new approach, by building international "coalitions of the willing" around specific shared goals and values.

Let me outline in a little more detail how I see this new form of diplomacy working in three areas: the campaign to ban anti-personnel mines, the battle against international drug smuggling, and countering human rights abuses.

"The global convention banning anti-personnel mines is one of the very few areas on the human security agenda where Canada and Korea do not see eye to eye. I am sensitive to the special sinuation of Korea in this regard, but I would like nonetheless to outline Canadia's thinking on the landmines ban, and the areas where I believe we can work together despite our different vicws.

The cunpaign to ban landmines was a response to the human security crisis that these weapons have caused. Its goal was to improve - or save - the lives of the many civilians threatened by these cheap, widespread killers. Those supporing the campaign do nor 
deny that, in sone circumstances, anti-personnel mines have a certain military utility: But we betieve that this atility is tar nuweighed by the thousands of civilian lives and acres of bond around the world that these weapons teke year after year kong after the war in which

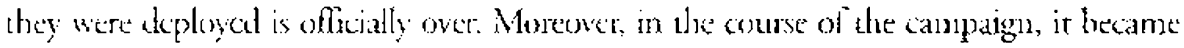
clear that atse only way to cond this mass destruction in stow motion was through a total batl on anci-personnel mines.

Since the signarue of the comention banning anti-personnel mines in Decentres. $199 \%$ momntum towards a global ban has continued. To datc, 129 countries have signed the Ottawa (omencion and 36 have ratifed it.' We hope to reach our groal of 40 ratilications this tall: which is the minimum number of ratitication required to anstom the convention inte international law.

We continue wo hope that the Republic of Korea will be able to sign the convention. Fint ar she same eime, we understand Korea s need ro ensure deterent capabiliries, given the volatile nusuce of the situation on the Korean l'enitnsula. As one of the comntries that

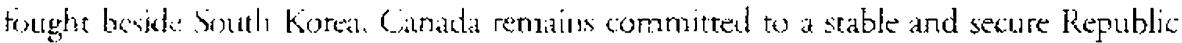

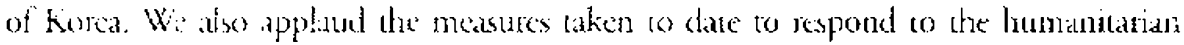

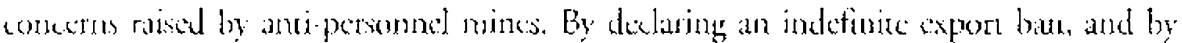

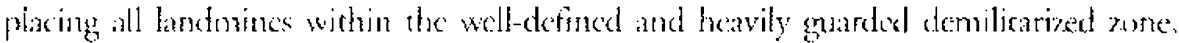
ROK bass ansured that innocent civitians are nest plut at risk.

Vonetheliss. the intermational commonty has created through the Ottawa

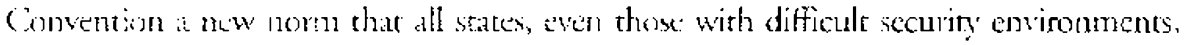
must move uswards. Military forces around the world ate adpoting to the new reality that

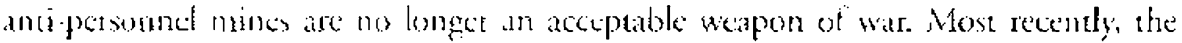

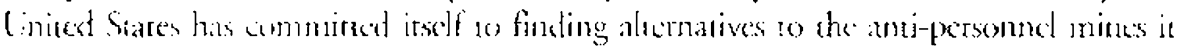
uses, and to signging the convention by 2000 . We are convinced that the Republic of Koreal will crentually be able to renounce anti-jetsonnd mines without compromising the effectivenes; of deferese, particularly given that the ban does not apply to mines triggered by tankis or other heary wehicies.

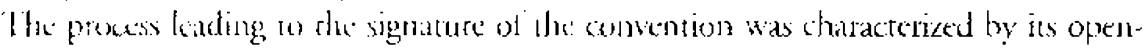

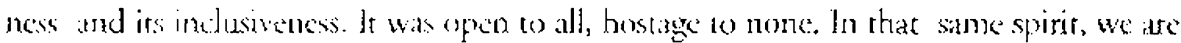
rady to conperite on minc iection de-mining and assistance so survivers with-all willing partnew, whether they have signed the convenrion or nor. Canaba has pledged $\$ 100$ million over live years toward mating the goals of the convention. and we are committed wo ensuring thin there is a coordinated international effort in mine action. I salute the comtributons dhat kurea has made to the LN mine action fiunds to dare. I hope that we will be able we woth togetler in the future in this area.

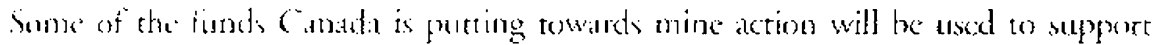
revearch on technology tor humantarian de-mining. We are also looking at aceptable and mote bumane allermatives to anti-persomed mines an aspect that might be of partic-

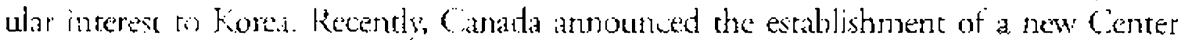
tor Minc-iktion Ieibnologies based at our Deferse Rescarch Eseablishment in Suffield. 
Alberta. It will undertake research on improved methods of mine-clcarance and more humane alcernatives to anti-personnel mines.

For most of our citizens, thankfully, anti-personnel mines are only a distant threat. But other threats to human security come much closer to home. The intermational trade in illegal drugs and other illicit substances, for example, affects both our countries. This is truly the dark side of globalization - when teenagers in Vancouver are overdosing on heroin from Burma that has transited through a third country, with the profits laundered through a fourth.

I'his is an area where, in my vicw, regional cooperation in butding innovatrive approaches can be extremely effective. Regional approaches allow is to tackle all stages of the problem in an inregrated way; from the supply end through the demand end of the equation. Korea has been at the forefront of regional cooperation on drugs, both under UN auspices and through regular liaison meetings of international anti-drug officials. Korea and Canada co-tunded a drug interdiction project in the Amazon region as part of a regional anti-drug strategy for the Americas.

lwo years ago, at my request, the issue was added to the agenda for discussions between Foreign Ministers from ASFAN countries and their dialogue partners. At our most recent meetings in Manila in July, we held fruiful discossions on this issue, which resulted in a number of practical proposals. Much remains to be ctone of course, but by establishing regular regional dialogues, I believe we have taken an important step in the right direcrions.

If I ware ro point to one aspect of human security where there is greatest scope for cooperation bewoen Koted and Canada, it would be human rights. I have already menrioned our great respect for President Kin and for the important steps he has taken to further the cause of human rights both at home and internationally. We share with him the view that this is equally important both as an cnd in itself and as a necessary condition for sustainable economic development. Long-term economic and social growth requires solid policies and institucions, built on a foundation of democracy, rights and justice.

I see growing opportunities for us to work togerher, starting from this shared viewpoint, to build the sort of new institutions and parnerships tequired to prorect human security and human rights in a changing world. In this context, I applaud President Kin's announcement of plans to cnact human righes law in Korea and establish a national human rights commission. Canada will be following closely these important developments.

Just before visizing Korca, I was in Rome, whete lengthy negotiations to cstablish an International Criminal Court ended in success. I am very please at the ourcome of the negotiations in Rome, which approved the crearion of an independent and effective Courc. 'This body will ace as a court of last resort, to ensure that those who commit the worst human rights abuses--genocide, war crimes, and crimes against humaniry- no longet do so with impunity. Canada and Korea, as mernhers of the like-minded group. worked long and hard rogether to ensure that this body is a court worth having. We can be proud that we have plaved a part in the founding of a key new international istsritu- 
rion, and that in the process, we have dereloped creative tools that will serve us well ar we lackle odher challenges ahe:as.

The establishenkent of the International Criminal Court and the signature of the conwenticu banging ant-personnel mines ave dear signs that we can make progress in tackling human securiry problems if wo are willing to he bold, and to undertake a new sryle of diplomacy. Now the internarional community is turning its attention to other pressing human scuriog probkerns as wetl, as attested by recont international conferences on child s'xual explotation. on the illicit clrug trade, and on small arms and light weapons.

This is not to say that the old problems of "hald sccurity" have disappcated. You have conly wo look num to fle demiliatized zone or west to where India and Pakistan have heen testing mulcas devices, we reognize this, The latter is an issue of grave concem to both ous comntries. India's actions have undemined thiry years of successful mantagemear of the nucker non prolitetation regimc, and constituti a serious threat to international and egrional sceurity. We cannot allow this to be the start of a new arms race in Asicl.

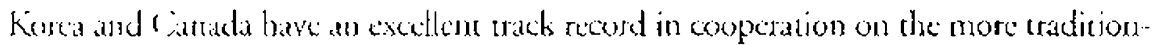

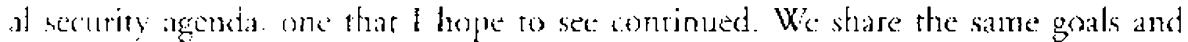

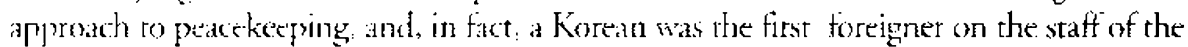
1..B. Pearion l'eacekceping Cenre. We are very pleased to set a Korean filling the post of UN Lnderscuctary-Cinceral lor peackeping. Since the early 1990's, we have expanded our acivities 10 promote regional security most renty through the arms control workshop heid foindy ast month by (juladat and the Korean Institure of Defense Analysis.

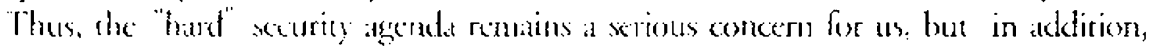
nes in exclusion of, the requiremosts of the humanitarian agenda. Canadats desire for an improved secuticy sicuation on the Korean Peninsula, for example, is matched by our

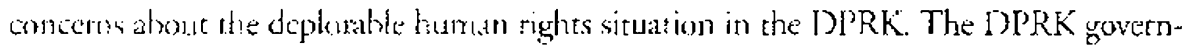
menc's unacceptable public denumiations of the International Covenant on Civil and Polterisal Rights only heightets these woncerns.

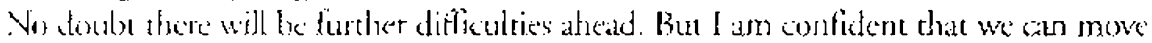
beyond them. Wo can a so by applying the pasitive lessons we have learned so far:

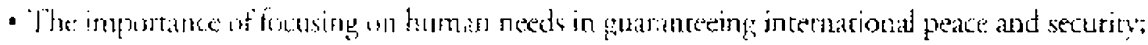

- Ihe uced for al anspaynt appresch that being stases and civil society in oper dialogue;

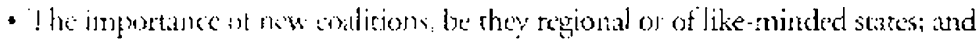

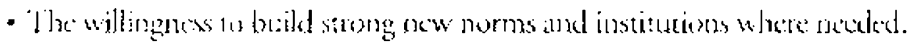

These ase in my vicw, key elements of a new diplomary that addesses the human security thatlenge: of our changing times. A new diplomacy that offers, I believe, even greater persibilities than before for cooperation between Korea and C.anada on the incerational seens. The establishment of the Internitional Criminal Court is only the firs exumple of what we, in pattership with one another and with other like-minded

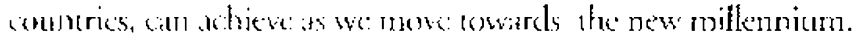




\section{The Landmines Campaign in Context}

\section{THE OITAWA PROCESS}

T The campaign to ban anti-personnel landmines had its roots in a growing awareness of the tru: nature of these woapons and the it etfeces. Ait workers, inedical personnel, members of non-governmental organizations and others saw firsthand the carnage that anti-personnel mines were causing: some 26,000 people killed or injured every year, most of them cisjians. They saw that anti-personnel mines were killing and wounding decades after the conflicts in which they were laid were over. They saw entire communities cerrorized and impowerished, and large traces of land rendered useless. And they saw a problen that was not going to go away, with pertaps as many as 100 million landmines deployed in 70 countries mainly in the developing work. Faced with a humanitarian crisis on this satic. they togan to speak out, and to mobilize public opinion.

As chis civil socier campaign took off in the carly 1990 's it focused increasingly on a total ban on anti-personnel mines at the only effective solution. Partial bans or restrictions on these smatl, cheap and relatively simple weapons would be too hard to enforce efectively. Morcover, many respeced miliary offiers isgre that anti-personnel mines are nos essontal w military operaions, and are frequendy mis-used. They arges that these weapons should he banued hecause their humanitarian consequences far ourweigh their limirad military valuc.

What has come to be known as the Ottawa Process grew out of two related strands: this civil society campaign, and efforts by some governments to rase the profile of the landmines issue in the concext of a review of the Convention on certain Conventional Weapons (C.CW). These two strands joined in 1996 at the firs of a series of infomal meerings in the margins of the CCW review berwen governnents and $\mathrm{NGCO}_{\mathrm{S}}$ (non governmetse organizarions) supportive of a ban on landmines.

In I eccmber 1996. Canada hosted a formal neeting of 50 pro-ban governments, 24 observer govenments and numerous non-governmental representatives. At the end of that conterence, I duallenged the global community to retuen to Otcasva by the end of 1907 o sign a conention banning landmines ouright. The Ottawa Process was laund hed, and a period of ineense work began.

A core group of commitred combries Austria, Belgium, Canada, Gromany. Ireland, Mexico, the Necherlands, Noway, the Philippines, South Africa and Switzerland - started at process that culnimated in the drafting and negotiation of the convention. As other

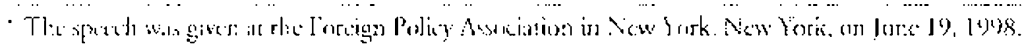


countries joined, momentum built. "The decision of Britain and France, foliowing general elections in both those countries, to join the ban campaign provided an invaluable boost to the process. In parallel with this process, we worked with non-governmental bodies to support a high-profile campaign to build grassroots support for the convention.

The result: in December, 1997, 123 countries signad a convention to eliminate the use, production, stockpiling, and transfer of anti-personnel mines, more signatories than even the most optimistic supporters had envisaged at the start of the process. Since that time another six countries have signed, bringing the total to date to 129 signatories. 'The ban represented a new norm in international disarmament. It was a major, though by no means final, step towards ending the humanitarian crisis caused by these weapons of slow-motion mass destruction. And it was backed up by commitments of close to half a billion dollars U.S. from the intenational community for the destnicion of stockpiles, de-mining, and assistance to victims.

The Octawa Process was exceptional on a number of fronts. A unique conalition of governments, civit sociery, and international groups worked dosely together to make the convention a reating: The convention broke records for the speed with which it was developed and negotiated, as well as for the number of signatories, and is now well on its way to breaking more recotds for spreed of entry inco force. As of early September, 36 signatories had rarified the convention. The 40 ratifications required for entry-into-force will almost certainly be reached by early fall, 1998. Perhaps most importandy, this Convention was the first international disarmament agteenent to ban a weapon in widespread, active use around the world.

\section{THE NEXT PHASE: MAKING THE BAN RFAL}

In Canada and elsewhere, atrencion is now focused on the next phase: ratification, universalization, and full implementation of the Convention. A central element of implementation is mine action. There is an urgent need to clear land of mines so that people can return to their homes and their livelihoorl. We must address the crucial long-term issuc of ensuring the rchabilitation of mine victims and their reintegration including social and economic into their socicties and into productive, meaningful lives.

Canada has allocated $\$ 100$ million over the next five years to these ends. It will fund projects such as a new Centre for Mine-Action Technologies based at our Defense Research Establishment in Sutfield. Alberta. The Centre will undertake research on improved methods of mine-clearance and more humane aternatives to anti-personnel mines.

Within the Department of Foreign Affairs and International Trade alone, we will devore over $\$ 6$ million this year to supporting ratification and universalization, and to building the United Nations capacity to co-ordinate global mine acrion. In cooperation with the Canadian military, we will use some of these funds to help others destroy stock-

\footnotetext{
1 As of luty 2. 1998.
} 
piles of anti-personnel mines. We will help our partners within civil society to develop their capacities in supporting and monitoring implementation. Canada will also be contributing to the massive task of clearing the millions of mines in the ground in Morambique, Angola, Central America, Cambodia, Afgharnisan, and clsewhere. As one of our first mine ascion projects, the Canadian Imernational Development Agency will put $\$ 10.5$ million over three vears into a progran to strengthen mine clearance efforts in Norarnbique.

As we work to expand support for the ban, the Uniced States' annourcement that it will sign the Ottawa Convention by 2006 was welcome news. It is a clear sign of the Iegitimaty and creditility, which the Convention has accuired. I do, however, haves reservations abour the major condirion that the US government has placed on signing the Consention: that of finding atternatives to anti-personnel mines. This is disturbing hecause it continues to cast the preblem as a military one, rather than the humanitarian isscte that it is. If this is truly what is standing in the way of the United States joining the Convention. I hope that it will commit serious energy and resources to finding those alcernatives, the same kind of encrgy that it has commited to humanitarian de-mining.

The United States says that it cannot sign the Ottawa Convention at present because of its "unique responsibilities." I would submit that part of Ancrica's global responsibili$\mathrm{ry}$ is to recognize that the world has changed, and that the old ways of doing business no longer hold. Other countrics have also argued that their special circumstances make it hard for then to sign the convention. Whatever rhe difficulties of their individual security environments, they have the responsibilicy to move towards the new international norm estatblished by the Otawa Convention.

\section{THE BROADER CONTEXT}

The success of the Ortawa P'rocess is in itself a clear indicator of this change. Exceptional as in is, the Ottawa lrocess did nor spring our of nowhere. It emerged from the scismic shifts that have realigned the tectonic plates of world affairs since the fall of the Berlin Wall. It is, I beieve, only the first example of an energing international response to these changes and the longer-term trends chat underlic them. After an ixirial periesd of paralysis in the face of the "new wotld disorder," the international community is starcing to develop new tools and new ways of doing business.

Broadly spraking. I see four crends, and four responses to them, that gave hirth to the Ottawa l'ocess. The four trends are as follows:

- First, a change in rlac nacure of the conflikt, with bitter interthal wass that primarily target civilian populdusns taking ower fron tradicional wars between states als the greater source of stolual instabilin?;

- Tecond, increasingly permeable internacional borders, through which people, intormation goids, narural resources and money pass for good or lor bad;

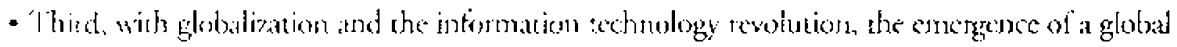


commons the Intertzet equivalent of Marshall McI.uhan's global village; and

- Fourth, a diffision of international power at the level of both state and non-state actors, which has led to a democratization of foreign policy. "This is due in part to the growing importance of what the American theorise Jascph Nye termed "sofi power.

\section{RESPONSES TO INTERNATIONAL TRENDS}

These trends have already been described extensively by observers of international aflairs, so I will not belabor them here. I would like to spend a litele more time, however, outlining four important aspects of the emerging international response to them. These fout aspects are:

- An approsach centered on human security,

- A retrewed focus on humaritariars standards;

- New forms of partnership; and

- Maxinum use of "soft power" through a combination of old and new tools of diplomacy.

Foreign Ministers used to be concerned above all with the security and integrity of the state. Increasingly, however, as borders become porous and the Cold War standoff is replaced by a multitude of intra-state conflicts, international decision-makers deal with issues that directly affect people's daily lives. Whether the focus is international crime, transboundary pollution or human rights abuses, our basic unit of analysis and concern has shrunk from the state to the community, and even to the individuat. It is in response to these devclopments that a "human security" approach has emerged, one which formulates securiry goals primarily in terms of human, rather than state, needs.

In this context, international humanitarian standards and humanitarian laws take on a new importance. As internal conflicrs increasingly target civilians, the old standards regarding use of certain classes of arms and treatment of individuals in times of war no longer provide sufficient protection.

The landnines annpaign slows how, by looking at a problem through a human securicy lens, we can apply the basic principles of humanitarian law in a new area to address a severe humanitarian crisis. The campaign stasted from the premise that the lives and limbs of millions of civilians take precedence over military and national security interests. On this basis, we were able to establish a new norm in international disarmament: an outright bat on landmines, on the grounds that risk of severe harm to civilians was inherent of this class of weapon.

If we fous the human security lens on other areas such as conflict prevention, environmental protection, or human rights, the inadequacy of existing tools of international diplomacy becomes clear. In Rwanda and in Bosnia, for example, the international community was unable to tespond effectively to complex internal conflicts. Based on the lessons learned from these faitures, it is working to develop new approaches, so far with mixể results. 
One positive outcome has been the development through creative ad-hoc means of new cooperative approaches to buman security problems. Perhaps the most striking aspect of the Orawa l'rocess was the unusual and successtul parnership forged by governments, international organizations, and civil sociery.

Dialogue, lobbying, and outrach between governments and civil society on internatinnal issues are not new. What was unusual about the Ottawa Process was that governments and civil socicty worked directly together as members of a team, with remarkable success. The process was open to all NGOs, governments, the Red Cross, even individuals and hostage to none. The only requirement to join was the acceptance of a single, utishakable botton line: that the only way to deal widh landmines effecively was to ban them outright.

A good deal of attention has been paid to the non-gowernmental members of the coalition. Deservedly so, since they played a crusial role, recognized by the awarding of the Nobel Peace Prize to the International Campaign to Ban Landmines (ICBI.) and its coordinator. Jody Williams. But governments had an equally important, if sometimes less visible, role to play. 'The real key to success was in how the players joined forces to work togrether.

As the Otawa Process moves inco its second phase, this remarkable "coalition of the willing" continaes to develop and thrive. Donor nations are working to coordinate demining and victim assistance cfforts, and to cteate synergies with the military, with $\mathrm{V}\left(\mathrm{i}^{(}\right)$, and with koul popularions on an unprecedented scale. I'his work may have significant long-term impact in terms of improving donot coordination in development axsistance.

It is though implementarion that the special nature of the kandmines Convention beconves apparant. It is nuch more than a simple treaty to control or ban a weapon. Instead, it provides a detailed, unambiguous framework for a full range of integrared mine action. Thus, the money pledged to support implementation is not simply increased funding to support "business as usual." Every time we take on an iniriative, we first ask ourselves: does this help us implement the Convention? Does it fit into our framework for coordinatcd universal action that transcends artificial barriers between humanitarian, developruent, and disamament goals?

Is is clear that we mest mobilize more resources for mine autions, hut in doing so we must assure our texparters and supporters that this will be money well spent. This requires that we rapidly learn and apply the lessons of the past five years of mine action. One of the strengtiss of the Ottawa Process was its ability to link the local to the global. As we work [o ensure that the Convention hecomes a real engine for change in the lives of chose affected ly landenins, we cannot lose sighe of the twernendous moral, political, and financial support that the grassmots of this nowement can provide co our collecrive efforts.

The landmines coalirion was cerainly unusual, but why was it so successful? In large parr, I believe. it was successful because it combined old-style diplomacy with high-tech advocacy to makc maximum use of its soft pwicr tesources.

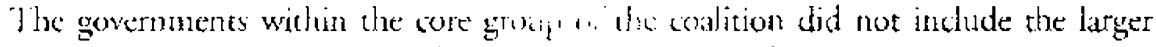
powers, but respeced conntries from across the range of the tradicional bard-power 
"pecking order." In the past, these countries would have been limited by the rigidities of Cold War alliances and divisions to acting as honest brokers. In the current more fluid international situation, however, the core group could use its skills in conmunicating, negotiating, mobilizing opinion, working within mululateral bodies, and promoting international initiatives to achieve the outcome we wanted.

The coalition was setting the international agenda and exerting international leadership in the face of lack of enthusiasm and even outright hostility on the part of some larger powers. This was soft power in action.

How did we do it? In part, through good old-fashioned diplomacy: a barrage of phone calls, letrers, demarches, corridor discussions, informal consultations, and formal negotiations at every level, from hads of government to junior officials. In pan, through using traditional tools in new ways: for example, through an extcnsive series of regional conferences to raise awarencss and build support for the ban, sponsored by governments with the ICBI. and the Red Cross. We also did it in part, through a high-rech advocacy cam. paign of the type not usually associated with the staid world of forcign policy.

The lare Princess Diana played an invaluable tole in bringing the landmines campaign into a million living rooms around the world to build understanding and support. At the same tinc, the cosalition used videos, newsletters, cell phones, and the Internet to build support for a ban within governments and civil society. If readers are interested in this aspect of the campaign, I would encourage them to visit the special landmines Web site established by Canada entitled "Safe-lane" (www.mines.gc.ca). We used this site to broadcast the proceedings of the signing conference in all UN langtages in real-time audio, another first for the Ortawa Process.

\section{FUTURE PROSPECTS: A NEW DIPLOMACY?}

The Ottawa Process is relatively new and it is still evolving. I believe it is a positive indicator of a new type of diplomacy suited to a new era, but 1 do not want to overstate the case. The proof of the process lies in the success of the next phase of the tandmines campaign entry into force and implementation and in the use of these ncw tools in other areas.

Another indicator of the success of this type of approach was the recent agreement to establish a permanent International (riminal Court (ICC). I helieve that an independent, effective ICC will be a key institution of the new siplomacy. It will help to deter some of the most serious violations of international humanitarian law. It will give new meaning and global reach to protecting the vulnerable and innocent. Isolating and stigmatizing those who commit war crimes or genocide and removing them from the community will belp to end the cycle of impuniry and retribution. Without justice, there is no reconciliarion, and withour reconciliation, there is no peace.

Nor do states need to fear intrusion by the ICC into their sovereignty. The principle of "complementarity" ensures that the Court will exercise jurisdiction where national systems are unable or unwilling to prosecure transgressors. It will be in a sense, a cour of last 
resort, a final bulwark to ensure that those who commit heinous crimes do not go unpunished.

In an era of declining state autonomy and power, we face the question of who, ultimately, decides issues of international morality and legality. Individual states! ithe international community? A "global commons" The Incermational Criminal Courc will help to resolve this dilemma by providing a respected, unbiased point of firal appeal. If we can establish new noms-- like the ban on anti-personnel mines- and new instirll. tions, like the ICCC - we will be laying the foundations of a new diplomacy focused on human needs. A similar approach may prove useful in addressing other human security concerns such as smatl arms proliferation, children s rights, including the recruiting of child soldiers, and hum an rights overall.

I know that there is segpticism in some quarters about the Oriawa Process and about the notions of soft power and human sccurity more generally. Supporers of a "realpolitik" view argue thar the end of the Cold War has simply returned the world to a balance of economic and military power. They may pride themselves on their hardheaded approach, but in fact, it is they who are refising to recognize that international realities have ithanged.

In a workd where (NiN brings every wat into gour living room, what use is military power alome if public opinion sharply restricts the circumstances in which in can be used? In a world where Foreign Ministers sit dowt to disuss global warming, base propaganda and child labor, it is clear that zero-sum applications of hard power are nor going to solve all the probleins we tace.

In my view, truc realism lies in recognizing that addressing non-traditional problems requires new approaches and tew tools. That the democratiaation of incernational relat-

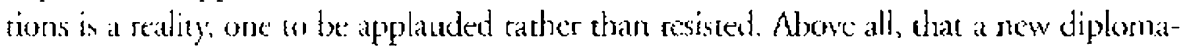
$g$ is urgenty required to address the challenges and opportunities of a newrera. 